ISSN 0258-7122

Bangladesh J. Agril. Res. 37(2): 207-213, June 2012

\title{
NITROGEN RESPONSE BEHAVIOUR OF DEVELOPED PROMISING LINES OF T.AMAN RICE
}

\author{
P. K. SAHA ${ }^{1}$, S. M. M. ISLAM ${ }^{2}$, M. AKTER ${ }^{3}$ AND S. K. ZAMAN ${ }^{4}$
}

\begin{abstract}
Nitrogen is the most limiting nutrient for rice. Modern high yielding rice varieties may have differences in accumulating and using $\mathrm{N}$ from soil and applied fertilizer. A field experiment with 8 rice genotypes was conducted during 2008 wet season (T.Aman season) to study the effect of different rates of $\mathrm{N}$ fertilization on the yield performance and nitrogen nutrition under irrigated condition. Among the tested varieties/lines, BR7155-20-1-3 produced the significantly highest grain yield of 5.04 t/ha at $\mathrm{N}_{30}$ level followed by Swarna (4.66 t/ha) at the same level of $\mathrm{N}$ with similar growth duration (140 days). Agronomic efficiency of added $\mathrm{N}$ ranged from 0.7 to 23.3 for the promising line BR7155-20-1-3 and 3.3 to 27.0 for variety Swarna. Grain yield at No was the highest in BR7155-20-1-3 followed by the variety Swarna and the lowest in BR7870-5 *(Nils)- I 0-HR8. Percent nitrogen recovery ranged from 50 to 63 for variety Swarna and 13 to 30 for promising line BR7155-20-1-3. The promising line BR7155- 20-1-3 and the variety Swarna may be economically advantageous over the other varieties/ lines.
\end{abstract}

Keywords: Rice genotypes, nitrogen uptake, nNitrogen use efficiency, nitrogen recovery.

\section{Introduction}

Among the essential plant nutrients, $\mathrm{N}$ is the key element for growing rice. This important element is found to be at a deficient level in most agricultural soils of the world including Bangladesh. The importance of $\mathrm{N}$ fertilizer in increasing yield is especially true for the modern high yielding varieties (HYVs) of rice (Lakhdive and Prasad, 1970; De Datta et al., 1974). But the estimated N use efficiencies by cereal crops in developing and developed countries are actually very low, namely 29 and $42 \%$, respectively (Raun and Johnson, 1999). A great part of the applied $\mathrm{N}$ is escaped to the environment through denitrification and volatilization (De Datta et al., 1991). Variety-specific $\mathrm{N}$ fertilizer recommendation may be one of the important options to increase $\mathrm{N}$ use efficiency in rice. Recent studies show that the modern rice varieties are different in the efficiencies in acquisition and physiological efficiencies (Bufogle et al.,

${ }^{1}$ Principal Scientific Officer, Soil Science Division, Bangladesh Rice Research Institute (BRRI), Gazipur-1701, ² Scientific Officer, Soil Microbiology Section, BRRI, Gazipur1701, ${ }^{3}$ Scientific Officer, Soil Science Division, BRRI, Gazipur-1701, ${ }^{4}$ Chief Scientific Officer and Head, Soil Science Division, BRRI, Gazipur-1701, Bangladesh. 
1997; Tirol-Padre et al., 1996 and Singh et al., 1998). It is necessary to know the $\mathrm{N}$ response behaviour of newly developed promising lines before recommending as varieties. So, this investigation was undertaken to determine the $\mathrm{N}$ response behaviour of 6 ALART materials viz. BR7155-20-1-3, BR7870-5*(Nils)-2-HR2, BR7870- 5*(Nils)-2-HR8, BR7870-5*(Nils)-7-HR1, BR7870-5*(Nils)-8-HR4, BR7870-5*(Nils)- 10- HR8 compared with two check varieties viz. Swarna and Guti-swarna

\section{Materials and Method}

The field experiment was conducted at the experimental farm of the Bangladesh Rice Research Institute, Gazipur, Bangladesh located at 2359' N latitude, $90^{\circ} 24$ E longitude during 2008 wet season (T.Aman season). The site is about $30 \mathrm{~m}$ above the mean sea level and has a subtropical climate, which is strongly influenced by south-western monsoons. The average annual rainfall is $2000 \mathrm{~mm}$ with more than $80 \%$ of it occurring from mid-June to the end of September. Mean temperature is the lowest $\left(15^{\circ} \mathrm{C}\right)$ in January and highest $\left(30^{\circ} \mathrm{C}\right)$ in May.

The soil of the experimental field is Grey-Terrace (Chhiata series). It is clayloam in texture with $\mathrm{pH}$ 6.8. Organic $\mathrm{C}$, total $\mathrm{N}$, available $\mathrm{P}$, and exchangeable $\mathrm{K}$ of the soil was $1.1 \%, 0.13 \%, 6.04 \mathrm{ppm}$, and 0.15 meq $/ 100 \mathrm{~g}$ soil, respectively. The available $S$ and Zn (EDTA extracted) of the soil were $6.78 \mathrm{ppm}$ and $2.1 \mathrm{ppm}$, respectively. Five doses of $\mathrm{N}$ i.e. $0,30,60,90$, and $120 \mathrm{~kg} / \mathrm{ha}$ were imposed as treatment. The experiment was laid out in a split-plot design with three replications. Nitrogen doses were assigned in the main plot and the varieties in the sub- plot. Each plot received a blanket dose of P, K, S, and $\mathrm{Zn}$ at the rate of 14-56-14-0 kg/ha, respectively, as STB. Six ALART materials viz. BR7155-201-3, BR7870-5*(Nils)-2-HR2, BR7870-5*(Nils)-2-HR8, BR7870-5*(Nils)-7HRl, BR7870-5*(Nils)-8-HR4, BR7870-5*(Nils)- 10-HR8 and two check varieties viz. Swarna and Guti-swarna were tested in T.Aman season. Thirty days old seedlings of each material were transplanted at $20 \mathrm{~cm} \times 20 \mathrm{~cm}$ spacing. Nitrogen from urea was applied in three equal splits $(1 / 3$ as basal $+1 / 3$ at active tillering stage (22 DAT) + 1/3 at 5-7 days before panicle initiation). Necessary intercultural operations were done as and when required. At maturity, the crop was harvested from $5 \mathrm{~m}^{2}$ areas at the centre part of each plot and 16 hills were collected for straw yield. The grain yield was recorded at $14 \%$ moisture content and straw yield as oven dry basis. Total nitrogen content from plant samples (grain and straw) of two materials (BR7155-20-1-3 and Swarna) was determined by the standard analytical procedure (Yoshida et al., 1976). Data were analyzed as per standard statistical procedure (IRRI, 1998). 


\section{Results and Discussion}

\section{Grain yield and agronomic efficiency}

All the varieties/lines, except BR7870-5*(Nils)-7-HRI and Guti-swarna (Ck), responded to applied $\mathrm{N}$ up to certain levels (Table 1). The variety Swarna (Ck), and the promising lines BR7155-20-1-3, BR7870-5*(Nils)-8-HR4 responded significantly to applied $\mathrm{N}$ up to $30 \mathrm{~kg} / \mathrm{ha}$, beyond this rate, grain yield decreased or increased slightly but the difference was not significant (Table 1). In case of BR7870-5*(Nils)-2-HR2 and BR7870-5 * (Nils)- 10-HR8, yield increase was significant up to $60 \mathrm{~kg}$ N/ha. In case of BR7870-5*(Nils)-2-HR8, N application only @ $90 \mathrm{~kg}$ N/ha significantly increased the grain yield over control. Analysis of variance for grain yield showed that the interaction effect of $\mathrm{N}$ rates and varieties/lines was highly significant $(\mathrm{P}<0.01)$. Among the tested materials, BR7155-20-1-3 produced the significantly highest grain yield of 5.04 t/ha at $N_{30}$ level followed by Swarna (Ck) (4.66 t/ha) at the same level of $\mathrm{N}$ with the same growth duration (140 days) (Table 1).

Table 1. Effect of $N$ rates on the grain yield ( $t / h a$ ) of $T$. Aman rice (ALART materials) at BRRI Farm, Gazipur, 2008.

\begin{tabular}{|c|c|c|c|c|c|c|c|c|}
\hline \multirow[b]{2}{*}{$\begin{array}{l}\mathrm{N} \text { rate } \\
(\mathrm{kg} / \mathrm{ha})\end{array}$} & \multicolumn{8}{|c|}{ Grain yield (tha-) } \\
\hline & $\begin{array}{c}\text { BR7155- } \\
20-1-3\end{array}$ & $\begin{array}{c}\text { BR7870- } \\
5 *(N i l s)- \\
\text { 2-HR2 }\end{array}$ & $\begin{array}{c}\text { BR7870- } \\
5 * \text { (Nils)- } \\
\text { 2-HR8 }\end{array}$ & $\begin{array}{c}\text { BR7870- } \\
\text { 5*(Nils)- } \\
\text { 7-HR1 }\end{array}$ & $\begin{array}{c}\text { BR7870- } \\
5 * \text { (Nils)- } \\
\text { 8-HR4 }\end{array}$ & $\begin{array}{c}\text { BR7870- } \\
5 * \text { (Nils)- } \\
\text { 10-HR8 }\end{array}$ & $\begin{array}{c}\text { Swarna } \\
\text { (Ck) }\end{array}$ & $\begin{array}{l}\text { Guti- } \\
\text { swarna } \\
(\mathrm{Ck})\end{array}$ \\
\hline $\mathrm{N}_{0}$ & 4.34 & 2.96 & 3.09 & 3.17 & 2.40 & 2.29 & 3.85 & 3.26 \\
\hline $\mathrm{N}_{30}$ & 5.04 & 3.38 & 3.60 & 3.58 & 3.54 & 3.06 & 4.66 & 3.08 \\
\hline $\mathrm{N}_{60}$ & 4.81 & 3.62 & 3.19 & 3.32 & 3.62 & 3.88 & 4.05 & 3.12 \\
\hline $\mathrm{N}_{90}$ & 5.17 & 3.77 & 3.88 & 3.70 & 3.93 & 3.28 & 4.46 & 3.23 \\
\hline $\mathrm{N}_{120}$ & 4.43 & 3.36 & 3.55 & 3.21 & 4.10 & 3.16 & 5.02 & 1.89 \\
\hline $\begin{array}{l}\text { Variety } \\
\text { mean }\end{array}$ & 4.76 & 3.42 & 3.46 & 3.39 & 3.52 & 3.13 & 4.41 & 2.91 \\
\hline $\begin{array}{l}\text { Duration } \\
\text { (days) }\end{array}$ & 140 & 118 & 118 & 126 & 118 & 118 & 140 & 140 \\
\hline
\end{tabular}

LSD 0.05 for Treat. X Var. $=0.56$, LSD 0.05 for Treat. mean $=0.40$, LSD 0.05 for Var. mean $=0.25$. $\mathrm{CV}(\%)=9.5$

At zero N, the promising line BR7155-20-1-3 produced the highest grain yield of $4.34 \mathrm{t} / \mathrm{ha}$ followed by Swarna (Ck) (3.85 t/ha) and Guti-swarna (Ck) (3.26 t/ha), while the promising line BR7870-5*(Nils)- 10-HR8 produced the lowest yield (2.29 t/ha). BR7155-20-1-3, BR7870-5*(Nils)-8-HR4 and Swarna (Ck) responded sharply to a low $\mathrm{N}$ dose, $30, \mathrm{~kg} / \mathrm{ha}$, no appreciable response of other lines/varieties was observed at that rate. The grain yield benefits obtained with $\mathrm{N}$ fertilization at $30 \mathrm{~kg} \mathrm{~N} / \mathrm{ha}$ were more than $1 \mathrm{t} / \mathrm{ha}$ for BR7870- $5^{*}(\mathrm{Nils})-8$ HR4, 0.8 t/ha for Swarna (Ck) and $0.7 \mathrm{t} / \mathrm{ha}$ for BR7155-20-1-3. At $60 \mathrm{~kg}$ N/ha, 
the grain yield benefit of $0.7 \mathrm{t} / \mathrm{ha}$ for BR7870-5*(Nils)-2-HR2, $1.59 \mathrm{t} / \mathrm{ha}$ for BR7870- 5*(Nils)-I0-HR8 and at $90 \mathrm{~kg} \mathrm{~N} / \mathrm{ha}, 0.8 \mathrm{t} / \mathrm{ha}$ for BR7870-5*(Nils)-2HR8 was obtained. Without applying any $\mathrm{N}$ fertilizer, the promising line BR7155-20-1-3 produced the highest grain yield (4.34 t/ha) followed by Swarna (3.85 t/ha). This finding suggested that the promising line BR7155-20-1-3 and the variety Swarna had the higher potential for utilizing native soil $\mathrm{N}$ for grain production than the other variety or promising lines. For this reason, the promising line BR7155-20-1-3 and the variety Swarna may be used as low input varieties for marginal farmers. It is worth while to mention that the variety Swarna and the promising line BR7155-20-1-3 have the same growth duration.

The differences in $\mathrm{N}$ response pattern among the studied varieties/lines were simply due to varietal difference. Varietal difference in N response was found in many previous investigations (De Datta, 1985; BRRI, 1985 and 1988; IRRI, 1987 and 1988, Choudhury and Bhuiyan, 1991). Agronomic efficiency (kg grain/kg added $\mathrm{N}$ ) also varied among the varieties /lines (Table 2). All the varieties/lines, except Guti-swarna, had the positive agronomic efficiency. Agronomic efficiency ( $\mathrm{kg}$ grain $/ \mathrm{kg}$ added $\mathrm{N}$ ) ranged from 0.7 to 23.3 in case of BR7155-20-1-3, 3.3 to 14.0 in case of BR7870-5*(Nils)-2-HR2, 3.8 to 17.0 in case of BR7870-5*(Nils)2-HR8, 0.3 to 13.7 in case of BR7870-5*(Nils)-7-HR1, 14.2 to 38.0 in case of BR7870-5*(Nils)-8-HR4, 7.3 to 26.5 in case of BR7870-5 * (Nils)- 10-HR8, 3.3 to 27.0 in case of Swarna and -0.3 to -11.4 in case of Guti-swarna. From the Table 2, it was shown that at lower $\mathrm{N}$ level, the value of AE is higher than that of higher $\mathrm{N}$ level.

Table 2. Agronomic efficiency of two modern varieties and 6 promising lines as affected by rates of $\mathbf{N}$ fertilization.

\begin{tabular}{|c|c|c|c|c|c|c|c|c|}
\hline \multirow[b]{2}{*}{$\begin{array}{l}\text { N-rate } \\
\text { (kg/ha) }\end{array}$} & \multicolumn{8}{|c|}{ Agronomic efficiency (kg grain/kg added N) } \\
\hline & $\begin{array}{c}\text { BR7155- } \\
20-1-3\end{array}$ & $\begin{array}{c}\text { BR7870- } \\
5 *(N i l s)- \\
2-H R 2\end{array}$ & $\begin{array}{c}\text { BR7870- } \\
\text { 5*(Nils)- } \\
\text { 2-HR8 }\end{array}$ & $\begin{array}{c}\text { BR7870- } \\
5 *(N i l s)- \\
7-H R 1\end{array}$ & $\begin{array}{c}\text { BR7870- } \\
5 * \text { (Nils)- } \\
\text { 8-HR4 }\end{array}$ & $\begin{array}{c}\text { BR7870- } \\
5 * \text { (Nils)- } \\
\text { 10-HR8 }\end{array}$ & $\begin{array}{l}\text { Swarna } \\
\text { (Ck) }\end{array}$ & $\begin{array}{c}\text { Guti- } \\
\text { swarna (Ck) }\end{array}$ \\
\hline $\mathrm{N}_{30}$ & 23.3 & 14.0 & 17.0 & 13.7 & 38.0 & 25.7 & 27.0 & -6.0 \\
\hline $\mathrm{N}_{60}$ & 7.8 & 11.0 & 1.7 & 2.5 & 20.3 & 26.5 & $3-3$ & -2.3 \\
\hline $\mathrm{N}_{90}$ & 9.2 & 9.0 & 8.8 & 5.9 & 17.0 & 11.0 & 6.8 & -0.3 \\
\hline $\mathrm{N}_{120}$ & 0.7 & 3.3 & 3.8 & 0.3 & 14.2 & 7.3 & 9.8 & -11.4 \\
\hline
\end{tabular}

\section{Straw yield}

All the varieties/lines, except BR7870-5*(Nils)-8-HR4 and BR7870-5*(Nils)-10HR8, responded to applied $\mathrm{N}$ up to certain levels (Table 3). The variety Swarna responded significantly to applied N up to $120 \mathrm{~kg} / \mathrm{ha}$. The variety Guti-swarna and BR7870-5*(Nils)-2- HR8 responded significantly up to $30 \mathrm{~kg} \mathrm{~N} / \mathrm{ha}$. But in case of BR7870-5* Nils)-2-HR2, straw yield increase was significant up to $60 \mathrm{~kg}$ 
N/ha. In case of BR7155-20-1-3 and BR7870-5*(Nils)-7-HR1 yield increase was significant up to $90 \mathrm{~kg} \mathrm{~N} / \mathrm{ha}$. The interaction effects of $\mathrm{N}$ rates and varieties/lines on the straw yield was also highly significant $(\mathrm{P}<0.01)$. Among the tested varieties/lines Swarna significantly produced the highest straw yield of $7.60 \mathrm{t} / \mathrm{ha}$ at $\mathrm{N}_{120}$ level followed by the Guti-swarna (5.80 t/ha at $\mathrm{N}_{30}$ level) and the promising line BR7155-20-1-3 (5.77 t/ha at $\mathrm{N}_{90}$ level).

Table 3. Effect of $N$ rates on the straw yield ( $t / h a)$ of T.Aman rice (ALART materials) at BRRI Farm, Gazipur, 2008.

\begin{tabular}{|c|c|c|c|c|c|c|c|c|}
\hline \multirow[b]{2}{*}{$\begin{array}{l}\text { N-rate } \\
\text { (kg/ha) }\end{array}$} & \multicolumn{8}{|c|}{ Straw yield (t/ha) } \\
\hline & $\begin{array}{c}\text { BR7155- } \\
20-1-3\end{array}$ & $\begin{array}{r}\text { BR7870- } \\
5 * \text { (Nils)- } \\
\text { 2-HR2 }\end{array}$ & $\begin{array}{l}\text { BR7870- } \\
\text { 5*(Nils)- } \\
\text { 2-HR8 }\end{array}$ & $\begin{array}{l}\text { BR7870- } \\
5 * \text { (Nils)- } \\
\text { 7-HRI }\end{array}$ & $\begin{array}{l}\text { BR7870- } \\
\text { 5*(Nils)- } \\
\text { 8-HR4 }\end{array}$ & $\begin{array}{l}\text { BR7870- } \\
5^{*} \text { (Nils)- } \\
\text { 10-HR8 }\end{array}$ & $\begin{array}{l}\text { Swarna } \\
\text { (Ck) }\end{array}$ & $\begin{array}{l}\text { Guti- } \\
\text { swarna } \\
\text { (Ck) }\end{array}$ \\
\hline $\mathrm{N}_{0}$ & 5.14 & 3.12 & 3.24 & 3.23 & 3.96 & 3.20 & 3.86 & 5.19 \\
\hline $\mathrm{N}_{30}$ & 5.26 & 3.69 & 4.29 & 3.06 & 3.66 & 3.66 & 5.30 & 5.80 \\
\hline $\mathrm{N}_{60}$ & 5.53 & 4.77 & 4.50 & 3.28 & 4.06 & 3.47 & 5.41 & 5.35 \\
\hline $\mathrm{N}_{90}$ & 5.77 & 3.83 & 4.03 & 4.11 & 3.30 & 3.68 & 6.51 & 6.28 \\
\hline $\mathrm{N}_{120}$ & 5.84 & 3.91 & 3.60 & 3.83 & 3.75 & 3.13 & 7.60 & 5.91 \\
\hline $\begin{array}{l}\text { Variety } \\
\text { mean }\end{array}$ & 5.51 & 3.86 & 3.93 & 3.50 & 3.75 & 3.43 & 5.74 & 5.71 \\
\hline
\end{tabular}

LSD 0.05 for Treat. X Var. $=0.59$, LSD 0.05 for Treat. mean $=0.58$, LSD 0.05 for Var. mean $=0.26 . \mathrm{CV}(\%)=8.1$

\section{Nitrogen nutrition, apparent $\mathbf{N}$ recovery and production efficiency}

From the above discussion, it may be concluded that the promising line BR715520-1-3 and the variety Swarna may be used as low input varieties for marginal farmers. So, the study of nitrogen nutrition, apparent $\mathrm{N}$ recovery and production efficiency was done on these two rice genotypes only.

Nitrogen concentration in grain was increased gradually due to increased , rate of $\mathrm{N}$ application up to $90 \mathrm{~kg} \mathrm{~N} / \mathrm{ha}$ in case of variety Swarna and up to $120 \mathrm{~kg}$ N/ha in case of BR7155-20-1-3 (Table 4). Nitrogen concentration in grain ranged from $1.12 \%$ to $1.68 \%$ for variety Swarna and $1.38 \%$ to $1.60 \%$ for promising line BR7155-20-1-3. Nitrogen content in straw ranged from $0.66 \%$ to $0.87 \%$ for variety Swarna and $0.60 \%$ to $0.72 \%$ for promising line BR7155-20-1-3. Total N uptake increased gradually due to $\mathrm{N}$ fertilization in both varieties/lines. Total $\mathrm{N}$ uptake $(\mathrm{kg} / \mathrm{ha})$ ranged from 74 to 136 for variety Swarna and 94 to 115 for promising line BR7155 -20-1-3 (Table 4).

Apparent recovery (\%) of added $\mathrm{N}$ varied due to variation of $\mathrm{N}$ rates and variety/line. Apparent recovery of added $\mathrm{N}$ decreased as $\mathrm{N}$ rate increased. It ranged from $50 \%$ to $63 \%$ for variety Swarna and 13\% to 30\% for promising line BR7155-20-1-3 (Table 4). Production efficiency (kg grain $/ \mathrm{kg}$ absorbed N) also 
varied due to variation of $\mathrm{N}$ rates and varieties/lines. It ranged from 34 to 52 for variety Swarna and 40 to 49 for the promising line BR715 5-20-1-3 (Table 4) and also decreased gradually as $\mathrm{N}$ rate increased in both varieties /line.

Table 4. Nitrogen nutrition, production efficiency and apparent recovery of added $\mathbf{N}$ by one variety and one promising line as affected by $\mathbf{N}$ fertilization.

\begin{tabular}{|c|c|c|c|c|c|c|c|c|}
\hline \multirow{2}{*}{$\begin{array}{l}\text { Variety } \\
\text { /line }\end{array}$} & \multirow{2}{*}{$\begin{array}{l}\mathrm{N} \text { rate } \\
\text { (kg/ha) }\end{array}$} & \multicolumn{2}{|c|}{$\mathrm{N}$ content (\%) } & \multicolumn{3}{|c|}{ Nitrogen uptake (kg/ha) } & \multirow{2}{*}{$\begin{array}{c}\text { Apparent } \\
\text { recovery } \\
\text { of added } \\
\mathrm{N}\end{array}$} & \multirow{2}{*}{\begin{tabular}{|} 
Production \\
efficiency \\
(kg \\
grain $/ \mathrm{kg}$ \\
absorbed \\
$\mathrm{N})$
\end{tabular}} \\
\hline & & Grain & Straw & Grain & Straw & Total & & \\
\hline \multirow[t]{5}{*}{ Swarna (Ck) } & $\mathrm{N}_{0}$ & 1.12 & 0.79 & 43 & 31 & 74 & - & 52 \\
\hline & $\mathrm{N}_{30}$ & 1.21 & 0.66 & 56 & 35 & 91 & 57 & 51 \\
\hline & $\mathrm{N}_{60}$ & 1.66 & 0.68 & 67 & 37 & 104 & 50 & 39 \\
\hline & $\mathrm{N}_{90}$ & 1.68 & 0.87 & 75 & 56 & 131 & 63 & 34 \\
\hline & $\mathrm{N}_{120}$ & 1.61 & 0.73 & 81 & 55 & 136 & 52 & 37 \\
\hline \multirow[t]{5}{*}{ BR7155-20-1-3 } & $\mathrm{N}_{0}$ & 1.38 & 0.67 & 60 & 34 & 94 & - & 46 \\
\hline & $\mathrm{N}_{30}$ & 1.40 & 0.60 & 71 & 31 & 102 & 27 & 49 \\
\hline & $\mathrm{N}_{60}$ & 1.49 & 0.72 & 72 & 40 & 112 & 30 & 43 \\
\hline & $\mathrm{N}_{90}$ & 1.47 & 0.68 & 76 & 39 & 115 & 23 & 45 \\
\hline & $\mathrm{N}_{120}$ & 1.60 & 0.66 & 71 & 39 & 110 & 13 & 40 \\
\hline $\operatorname{LSD}(0.05)$ & - & 0.27 & NS & 14.56 & 6.47 & 14.87 & - & - \\
\hline CV (\%) & - & 10.2 & 10.0 & 11.8 & 9.0 & 7.6 & - & - \\
\hline
\end{tabular}

\section{Conclusion}

It may be concluded that among the tested materials, BR7155-20-1-3 and Swarna (Ck) produced the highest grain yield at $\mathrm{N}_{30}$ level with the same growth duration (140 days) in T.Aman season.

\section{References}

Bangladesh Rice Research Institute (BRRI). 1985. Annual Report for 1984. BRRI, Joydebpur. pp. 17-19.

Bangladesh Rice Research Institute (BRRI). 1988. Annual Report for 1986. BRRI, Joydebpur. pp.6-15.

Bufogle, A. Jr., P. K. Bolick, J. L. Kover, R. F. Macchiaveli and C. W. Lindau. 1997. Rice variety differences in dry matter and nitrogen accumulation as related to plant stature and maturity group. J. Plant Nutr. 20: 1203-1224.

Choudhury, A. T. M. A. and N. I. Bhuiyan. 1991. Yield and nitrogen nutrition of modern rice as affected by nitrogen fertilization under irrigated culture. Bangladesh Rice J. 2(1\&2): 122-127. 
De Datta, S. K. 1985. Availability and management of nitrogen in wetland lowland rice in relation to soil characteristics. In Wetland Soils: Characterization, Classification and Distribution. International Rice Research Institute. Los-Banos, Philippines. pp. 247267.

De Datta, S. K., R. J. Buresh, M. I. Samsom, W. N. Obcemea and J. G. Real. 1991. Direct measurement of ammonia and denitrification fluxes from urea applied to rice. Soil Sci. Soc. Am. J. 55: 543-548.

De Datta, S. K., F. A. Saladaga, W. N. Obcemea and T. Yoshida. 1974. Increasing efficiency of fertilizer nitrogen in flooded tropical rice. pp. 265-288. In The Fertilizer Association of India. Proc. FAJ-FAO Seminar on optimizing agricultural production under limited availability of fertilizer, New Delhi.

International Rice Research Institute (IRRI). 1987. Annual Report for 1986. IRRI, LosBanos, Philippines. pp. 8-11.

International Rice Research Institute (IRRI). 1988. Annual Report for 1987. IRRI, LosBanos, Philippines. pp. 10-21.

International Rice Research Institute (IRRI). 1998. International Rice Research Institute Irristat for windows, Version 4. 1, Biometrics unit, International Rice Res. Inst. Philippines.

Lakhdive, B. A. and R. Prasad. 1970. Yield of a tall and a dwarf indica rice as affected by fertilizer nitrogen, with and without nitrification inhibitors. J Agric. Sci. 75(3): 375379.

Raun, W. R. and G. V. Johnson. 1999. Improving nitrogen use efficiency for central production. Agron. J. 91: 357-363.

Singh, U., J. K. Ladha, E. G. Castillo, G. C. Punzalan, A. Tirol-Padre and M. Duqueza. 1998. Genotypic variation in nitrogen use efficiency in medium- and long-duration rice. Field Crops Res. 58: 35-53.

Tirol-Padre, A., J. K. Ladha, U. Singh, E. Laureles, G. Punzalan and S. Akita. 1996. Grain yield performance of rice genotypes at sub-optimal levels of soil $\mathrm{N}$ as affected by $\mathrm{N}$ uptakes and utilization efficiency. Field Crops Res. 46: 127-142.

Yoshida, S., D. A. Forno, J. H. Cock and K. A. Gomez. 1976. Laboratory Manual for Physiological Studies of Rice. Third Edition. International Rice Research Institute (IRRI), Los Banos, Philippines. pp. 14-16. 